\title{
Application of PCR-DGGE to the study of dynamics and biodiversity of microbial contaminants during the processing of Hibiscus sabdariffa drinks and concentrates
}

\author{
Ndeye Adiara Ndiaye ${ }^{1, \star}$, Yasmine Hamdouche ${ }^{2}$, Alé Kane ${ }^{1}$, Mady $_{\text {Cissé }}{ }^{1}$, Laurent Berthiot ${ }^{2}$, \\ N. Coumba Touré-Kané ${ }^{1}$ and Didier Montet $^{2}$ \\ 1 Polytechnic college of Dakar, BP 5080 Dakar Fann, Senegal \\ 2 Cirad, UMR 95 Qualisud, TA B-95/16, 34398 Montpellier cedex 5, France
}

Received 17 February 2015 - Accepted 13 January 2016

\begin{abstract}
Introduction. Bissap (Hibiscus sabdariffa L.) is a common plant in the tropics. In Senegal, the calyces are used to make a popular juice. In the food industry, small and medium-sized enterprises (SMEs) are responsible for the transformation of bissap calyces into drinks, concentrates, jam, etc. In spite of the very low $\mathrm{pH}$ of the juice $(\mathrm{pH}<3)$, problems of contamination and fermentation are often observed in the final products post-pasteurization. They are mainly due to Pseudomonas spp., E. coli, Klebsiella spp. and Pichia opuntiae. To solve this issue, monitoring of the microbial ecology was performed during the full process of bissap products. Methods and results. Fresh calyces and dried mixed calyces of the two varieties of Hibiscus sabdariffa ('Koor' and 'Vimto'), as well as juice samples, were collected at every stage of the processing of a bissap drink and syrup in a Senegalese SME. The monitoring of microbial flora was performed by using molecular fingerprinting. The molecular technique PCR-DGGE was employed to evaluate the microbial dynamics using bacterial 16S rDNA, yeast 26S rDNA and 28S rDNA mold profiles at each critical stage of the process. Results and discussion. The genetic profiles generated contributed to identifying the critical points in the manufacturing processes. A multivariate analysis based on the presence or absence of spots in the denaturing gradient electrophoresis gels (DGGE) showed that the microbial flora (bacteria, yeasts, molds) of bissap evolved during the following phases: harvest (fresh flower), drying (dried calyces) and processing (before filtration, after pasteurization and before packaging). Conclusion. Our work contributed to determining the microorganisms responsible for the microbial contamination of the final products, and highlighted the origin of these contaminants. The most important critical point was identified as the pasteurization step.
\end{abstract}

Keywords: Senegal / bissap / Hibiscus sabdariffa / food contamination / microorganisms / PCR-DGGE / safety

\begin{abstract}
Résumé - Application de la PCR-DGGE à l'étude de la dynamique et de la biodiversité des contaminants microbiens au cours de l'élaboration des boissons et des concentrés d'Hibiscus sabdariffa. Introduction. Le bissap (Hibiscus sabdariffa L.) est une plante répandue sous les tropiques. Au Sénégal, les calices sont utilisés pour élaborer une boisson populaire. Dans l'industrie alimentaire, les petites et moyennes entreprises (PME) sont responsables de la transformation des calices de bissap en jus, en concentré, en confiture etc. En dépit du très faible pH du jus $(<3)$, des problèmes de contamination et de fermentation sont souvent observés sur les produits finaux après pasteurisation. Ils sont principalement dus à Pseudomonas spp., Escherichia coli, Klebsiella spp. et Pichia opuntiae. Pour résoudre ce problème, un suivi de l'écologie microbienne a été réalisé au cours du processus complet d'élaboration des produits du bissap. Matériaux et méthodes. Des échantillons de calices frais et de jus ont été prélevés à chaque étape de l'élaboration industrielle du jus et du sirop de bissap. Le suivi de la flore microbienne a été effectué en utilisant des empreintes moléculaires. La technique moléculaire de PCR par électrophorèse en gradient de gel dénaturant (DGGE) a été utilisée pour évaluer la dynamique microbienne en utilisant des profils bactériens d'ADNr $16 \mathrm{~S}$, d'ADNr $26 \mathrm{~S}$ de levures et d' $\mathrm{ADNr} 28 \mathrm{~S}$ de moisissures à chaque étape critique du processus. Résultats et discussion. Les profils génétiques générés ont contribué à identifier les points critiques dans les procédés de fabrication des boissons. Une analyse multivariée basée sur la présence ou l'absence de spots sur gels DGGE a montré que la flore microbienne (bactéries, levures, moisissures) du bissap a évolué au cours des phases suivantes : la récolte (de fleurs fraîches), le
\end{abstract}

\footnotetext{
^ Corresponding author: ndadiara@hotmail.com
} 
séchage (calices séchés), et le traitement (avant la filtration, après la pasteurisation, et avant l'emballage). Conclusion. Notre étude a bien contribué à déterminer les micro-organismes responsables des contaminations microbiennes des produits finaux, et à souligner l'origine de ces contaminants. Le point critique le plus important du processus industriel a été identifié comme étant l'étape de pasteurisation.

Mots clés : Sénégal / bissap / Hibiscus sabdariffa / contamination alimentaire / micro-organismes / PCR-DGGE / sécurité sanitaire des aliments

\section{Introduction}

The various parts of the Hibiscus sabdariffa L. plant are used in human food, in pharmaceuticals, and in the foodprocessing and textile industries [1]. Calyces constitute the most used part in the food-processing industry [1]. They are used in the manufacturing of thirst-quenching and tonic drinks, concentrates, jams, powders, etc. [1].

The origin of Hibiscus sabdariffa is unclear because for some it is a native of the region covering India and Malaysia [2], while others argue that it is in Central America [3], and a third group says Hibiscus sabdariffa comes from tropical Africa. Hibiscus sabdariffa is named differently in different African countries: bissap in Senegal, sorrel in Guinea and kakardé in North Africa [1,4].

In Senegal, two types of Hibiscus sabdariffa are found: the green and red types. The green type is mainly used as a condiment in sauces (calyx) and as vegetable leaves in food $[6,7]$. The red type, used mainly for juices, includes four varieties: 'Koor', 'Thai', 'CLT 92' and 'Vimto'.

The artisanal processing is mainly carried out by women associated with Groups of Economic Interest (GIE) [8]. The industrial production of bissap calyces is mainly done by the company Setexpharm (study and exploitation of vegetables for pharmaceutical uses), based in Dakar [8].

Drinks and concentrates made of Hibiscus sabdariffa are very appreciated in Senegal because of their nutritional wealth and therapeutic virtues assured by certain physical, chemical and biochemical constituents [1]. The microbiological quality and the stability of the drinks and concentrates depend particularly on the quality of the raw materials, the formulations and the different technological steps (pasteurization, presence of additives, final $\mathrm{pH}$ ) [9].

Our purpose was to monitor the microflora of contamination during bissap drink and concentrate processing, to estimate microbiological critical control points and to improve the quality and safety of products. For that purpose, the PCRDGGE, a molecular global method of analysis of the microbial DNA, was used to follow the various microbial microorganisms (bacteria, yeasts and molds) at the various stages of the bissap transformation into the drink and concentrate. This method is based on a one-step PCR followed by electrophoresis on denaturing gradient gel, which permitted analyzing DNA amplicons of the same size extracted from the microorganisms (bacteria, yeasts, molds) present in all samples. The amplicons of interest were then sequenced to identify the microorganisms.

\section{Materials and methods}

\subsection{Diagnosis of manufacturing processes}

Diagnosis was made with the consent and full cooperation of the company. It was conducted by a team of two people. Their role was to monitor all stages of the process from the raw material to end product.

\subsection{Physical and chemical analyses}

All reagents used were of analytical grade and were purchased from Sigma (L'Isle d'Abeau, France). Some physicochemical parameters were measured in the finished products (drink and concentrate) of Hibiscus sabdariffa using standard methods: titratable acidity, $\mathrm{pH}$ and dry matter [10]. Total titratable acidity was determined with a TitroLine Easy titrator (Schott Instruments, Mainz, Germany), using $0.1 \mathrm{~N} \mathrm{NaOH}$ solution. The $\mathrm{pH}$ value was determined using a calibrated $\mathrm{pH}$ meter and dry matter was determined by drying a 5-g sample at $105{ }^{\circ} \mathrm{C}$ up to constant weight $(24 \mathrm{~h}$ minimum). Total soluble solids (TSS) content was measured with an Abbe refractometer (Atago, Tokyo, Japan). Total anthocyanin content was assessed by the $\mathrm{pH}$ differential method at $\mathrm{pH} 1.0$ and $\mathrm{pH} 4.5$ [11]. The total phenolic content was determined with Folin-Ciocalteu reagent, according to the method optimized by George $e t$ al. [12]. Total and reducing sugars were determined using the Luff-Schoorl method [13].

\subsection{Sampling for analysis by molecular biology}

Fresh fruits of the varieties of Hibiscus sabdariffa L. var. Koor and Vimto were collected in the plantations of Niayes in the Dakar region in Senegal. Then, in a Senegalese SME, samples were taken at every stage of processing of the bissap into drink and syrup: the raw material, drink and syrup before filtration, after filtration, sweetened, pasteurized and conditioned (figure 1). Sampling consisted of fresh fruits of var. Koor and Vimto, and the dried mixture of both varieties collected in sterile Stomacher bags, by sampling carried out in $50-\mathrm{mL}$ Falcon tubes at all stages of the process and 250-mL bottles of the packed final products. Samples were frozen in Senegal and carried by the author by plane to Montpellier ( $8 \mathrm{~h}$ ) and kept frozen at $-20{ }^{\circ} \mathrm{C}$ until analysis. 


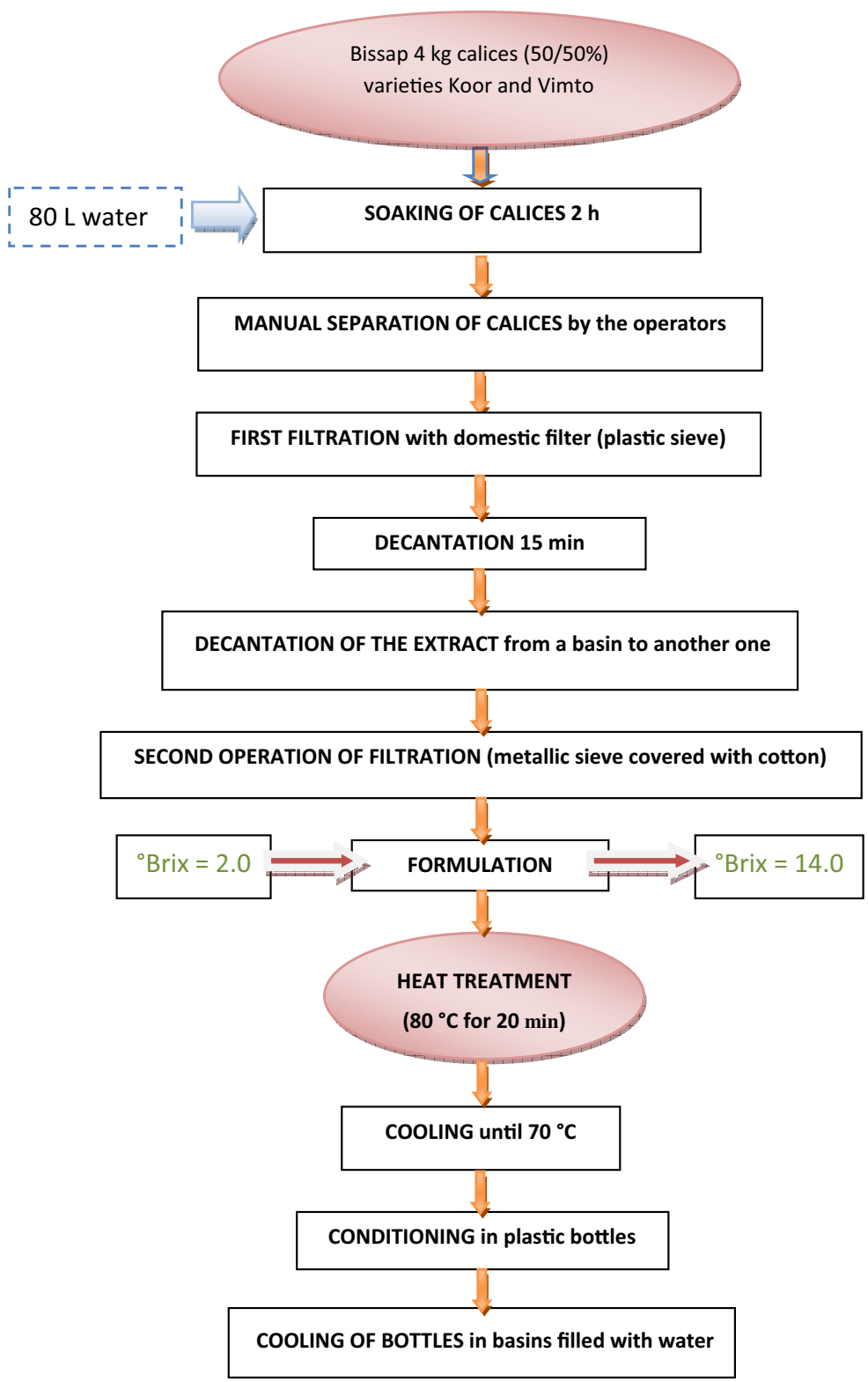

Figure 1. Logic flow in the process of bissap drink/juice (Hibiscus sabdariffa L.).

\subsection{PCR-DGGE methods}

\subsubsection{Extraction of microbial DNA from bissap samples}

Two $g$ of fresh fruits or dried bissap were weighed aseptically and placed in sterile tubes of $50 \mathrm{~mL}$ containing $10 \mathrm{~mL}$ of sterile peptone water. For other liquid samples, the samples were directly put into sterile tubes of $50 \mathrm{~mL}$. Tubes were homogenized for $30 \mathrm{~min} .2 \mathrm{~mL}$ of the supernatant were shared between two Eppendorf tubes of $2 \mathrm{~mL}$ containing $3 \mathrm{~g}$ of glass beads from 425 to $600 \mu \mathrm{m}$ (Sigma, France). Tubes were vortexed for $2 \mathrm{~min}$, and then centrifuged at 12,000 g for $10 \mathrm{~min}$ (Thermo Scientific, USA). The pellet was dissolved in $300 \mu \mathrm{L}$ of lysis buffer (2\% Triton X-100, $1 \%$ SDS, $100 \mathrm{mM} \mathrm{NaCl}$, $10 \mathrm{mM}$ buffer $\mathrm{pH} 8,1 \mathrm{mM}$ EDTA, pH8) and incubated for $5 \mathrm{~min}$ at room temperature $\left(25^{\circ} \mathrm{C}\right)$ in $100 \mu \mathrm{L}$ of lysis buffer
TE (Tris- $\mathrm{HCl} 10 ; 1 \mathrm{~mm}$ EDTA, $\mathrm{pH}$ 8, Promega, France) and $100 \mu \mathrm{L}$ of solution of lysozyme $\left(25 \mathrm{mg} \mathrm{mL}^{-1}\right.$ Eurobio, France) were added to the tubes, which were left for $5 \mathrm{~min}$, then $100 \mu \mathrm{L}$ of proteinase $\mathrm{K}$ solution $\left(20 \mathrm{mg} \mathrm{mL}^{-1}\right.$, Eurobio, France) were added to each tube and they were incubated at $42{ }^{\circ} \mathrm{C}$ for $20 \mathrm{~min}$. Then, $50 \mu \mathrm{L}$ of $20 \%$ SDS (sodium dodecyl sulfate, Sigma, France) were added to each tube and the tubes were incubated at $42{ }^{\circ} \mathrm{C}$ for $10 \mathrm{~min}$. A volume of $400 \mu \mathrm{L}$ of MATAB (Mixed Alkyltrimethyl Ammonium Bromide, Sigma, France) was added to each tube and the tubes were incubated at $65^{\circ} \mathrm{C}$ for $10 \mathrm{~min}$. Lysates were then cleaned by repeated extraction with $700 \mu \mathrm{L}$ of phenol/chloroform/isoamylic alcohol (25/24/1, V/V/V Carlo Erba, France), and the residual phenol was eliminated by extraction with an equal volume of chloroform/isoamylic alcohol (24/1 V/V). DNA was precipitated 
in isopropanol and $30 \mu \mathrm{L}$ of sodium acetate ( $3 \mathrm{M}, \mathrm{pH}$ 5), then stored at $-20{ }^{\circ} \mathrm{C}$ overnight. The DNA was washed with ethanol 70\%, and then dried by air at room temperature. Finally, the DNA was put in suspension in $100 \mu \mathrm{L}$ of ultrapure water and kept at $4{ }^{\circ} \mathrm{C}$ until analysis. The extractions of DNA were made according to the protocols of El Sheikha et al. $[14,15]$. All the experiments were done in duplicate. To control the DNA quality, migration on agarose gel electrophoresis was done. For that purpose, $5 \mu \mathrm{L}$ of DNA was mixed with $2 \mu \mathrm{L}$ of orange blue dye and analyzed on a $0.8 \%$ agarose gel. The gel was plunged into a TAE $1 \mathrm{X}$ buffer $(40 \mathrm{mM}$ Tris- $\mathrm{HCl}, \mathrm{pH} 7.4,20 \mathrm{mM}$ of sodium acetate, $1.0 \mathrm{mM} \mathrm{Na} 2_{-}^{-}$ EDTA (Eppendorf, Germany)).

After migration at $100 \mathrm{~V}$ for $30 \mathrm{~min}$, the gels were dipped for $15 \mathrm{~min}$ in a solution of ethidium bromide, then rinsed with some distilled water for $5 \mathrm{~min}$, and finally observed under UV using the GelSmart 7.3 software (Clara Vision, Les Ulis, France). The photos were taken by an integrated camera (Scion Co., USA).

\subsubsection{Analysis of the microbial flora by PCR-DGGE (Denaturing Gradient Gel Electrophoresis)}

A PCR was carried out on the DNA microbial extracts. The final volume was $50 \mu \mathrm{L}$ and it consisted of $5 \mu \mathrm{L}$ of $10 \mathrm{X}$ Buffer (Promega), $3 \mu \mathrm{L}$ of $\mathrm{MgCl}_{2}, 1 \mu \mathrm{L}$ deoxyribonucleotide triphosphates (dNTPs) and $10 \mu \mathrm{L}$ of primer solution $(0.2 \mu \mathrm{M})$. The primers were GC-338F (5-GCG CCG CCG CGC GCG GCG GGC GGG GCG GGG GCA CGG GGG GCA TCC TAC GGG AGG CAG CAG-3', Sigma) and 518R (5-ATT ACC GCG GCT GCT GG-3', Sigma) for bacteria [16]; GCU1 (5-CGC CCG CCG CGC GCG GCG GGC GGG GGG GTG AAA TTG TTG AAA GGG AA-3', Sigma) and U2 (5GAC TCC TTG GTC CGT GTT-3, Sigma) for molds [15] and GC-NL1 (5-CGC CCG CCG CGC GCG GCG GGC GGG GCG GGG GCC ATA TCA ATA AGC GGA GGA AAA G-3, Sigma) and LS2 (5-ATT CCC AAA CAA CTC GAC TC-3, Sigma) for yeasts [14]. Taq polymerase (Promega) $0.25 \mu \mathrm{L}$, 1-5 $\mu \mathrm{L}$ DNA and $15.75-19.75 \mu \mathrm{L}$ pure water (5 PRIME Gmbh, Hamburg, Germany) were added. The mixture was deposited in a PCR plate covered by Parafilm ${ }^{\circledR}$. The plate was put in a thermocycler (Bio Rad, USA). The amplification was done at first by denaturation of the DNA at $94{ }^{\circ} \mathrm{C}$ for $3 \mathrm{~min}$, hybridization at $55{ }^{\circ} \mathrm{C}$ (bacteria) or $52{ }^{\circ} \mathrm{C}$ (yeasts) or $50{ }^{\circ} \mathrm{C}$ (molds), then polymerization at $72{ }^{\circ} \mathrm{C}$ for $30 \mathrm{sec}$ and a final extension at $72^{\circ} \mathrm{C}$ for $5 \mathrm{~min}$. A total of 35 cycles were carried out.

The amplifications obtained by PCR were verified by classic electrophoresis on a $2 \%$ agarose gel with a TAE $1 \mathrm{X}$ buffer as an eluent. After migration at $100 \mathrm{~V}$ for $30 \mathrm{~min}$, the gels were stained in an ethidium bromide solution and quantified by using a standard of DNA of $100 \mathrm{pb}$ (Promega). PCR amplicons were analyzed by DGGE by using a system of detection of universal mutation (Bio Rad Dcode TM, USA) using the procedure described by El Sheikha [14]. $30 \mu \mathrm{L}$ of amplicon PCR was deposited in $8 \%(\mathrm{p} / \mathrm{v})$ polyacrylamide gel then eluted in a TAE $1 \mathrm{X}$ buffer.

The gels were submitted to electrophoresis at $20 \mathrm{~V}$ for $10 \mathrm{~min}$ then $80 \mathrm{~V}$ for $12 \mathrm{~h}$ as regards bacteria and yeasts [14], whereas for molds, $20 \mathrm{~V}$ for $10 \mathrm{~min}$ and $80 \mathrm{~V}$ for $16 \mathrm{~h}$ were needed [14]. After electrophoresis, the gels were colored for $30 \mathrm{~min}$ in an ethidium bromide solution and rinsed in distilled water for $20 \mathrm{~min}$ then photographed on a UV transilluminator with the Smart Gel 7.3 system (Clara Vision, Les Ulis, France).

\subsubsection{Purification and sequencing of DGGE bands}

Some discriminate bands that persisted at all stages of the process were extracted from the DGGE gel and put into Eppendorf tubes with $100 \mu \mathrm{L}$ of TE, and stored at $4{ }^{\circ} \mathrm{C}$ overnight. The tubes were incubated at $37^{\circ} \mathrm{C}$ for $1 \mathrm{~h}$. A volume of $50 \mu \mathrm{L}$ of cleansed DNA and $250 \mu \mathrm{L}$ sodium acetate was mixed in another tube. One $\mathrm{mL}$ of ethanol $100 \%$ was added to each tube and the tubes were incubated at $-20{ }^{\circ} \mathrm{C}$ for $30 \mathrm{~min}$. The tubes were then homogenized for $15 \mathrm{~min}$ and the DNA was washed with $500 \mathrm{~mL}$ of $70 \%$ ethanol for $5 \mathrm{~min}$. The tubes were dried by air at room temperature and finally, the DNA was put in suspension in $25 \mu \mathrm{L}$ ultra-pure water.

The cleansed DNA was sent for sequencing to GATC Biotech (Germany). Sequencing was performed on each of the duplicate PCR products' discriminate cut strips. The sequences obtained were aligned by means of a software sequence scanner (Sequence Alignment Editor Version on 1.0) following ClustalW Multiple Alignment [17].

\subsubsection{Statistical Analysis of the images obtained by DGGE}

Images of gels were straightened and aligned by using the ImageQuant TL 7.0 software (GE Healthcare, USA). This software allowed identifying bands and their relative positions. Data analysis was done by using the Dice coefficient of similarity (SD), which is calculated according to the formula [18]:

$$
\mathrm{SD}=2 \mathrm{Nc} / \mathrm{Na}+\mathrm{Nb}
$$

where $\mathrm{Na}$ is the number of bands detected in the sample $\mathrm{A}$, $\mathrm{Nb}$ is the number of bands detected in the sample $\mathrm{B}$, and $\mathrm{Nc}$ is the number of bands common to both samples.

The index of similarity is expressed between 0 (totally dissimilar) and 100 (perfect similarity). Cluster analysis was performed using the similarity matrix to group samples according to their similarity index using Primer Version 6 software.

\section{Results and discussion}

\subsection{Determination of sampling points during manufacturing processes}

Diagnosis of several processes permitted us to establish the flow sheet (figures 1 and 2). Sampling points were: fresh calyces, dried calyces, bissap extract before filtering (after soaking and manual separation of calyces and water), after filtration (with a 1-mm sieve and then $0.1 \mathrm{~mm}$ in diameter), after formulation (adding sugar: $135 \mathrm{~g} \mathrm{~L}^{-1}$ for juice and $1.2 \mathrm{~kg}$ for syrup), after pasteurization $\left(80^{\circ} \mathrm{C}\right.$ for $\left.20 \mathrm{~min}\right)$ and after conditioning of Hibiscus sabdariffa extract in plastic bottles by operators 


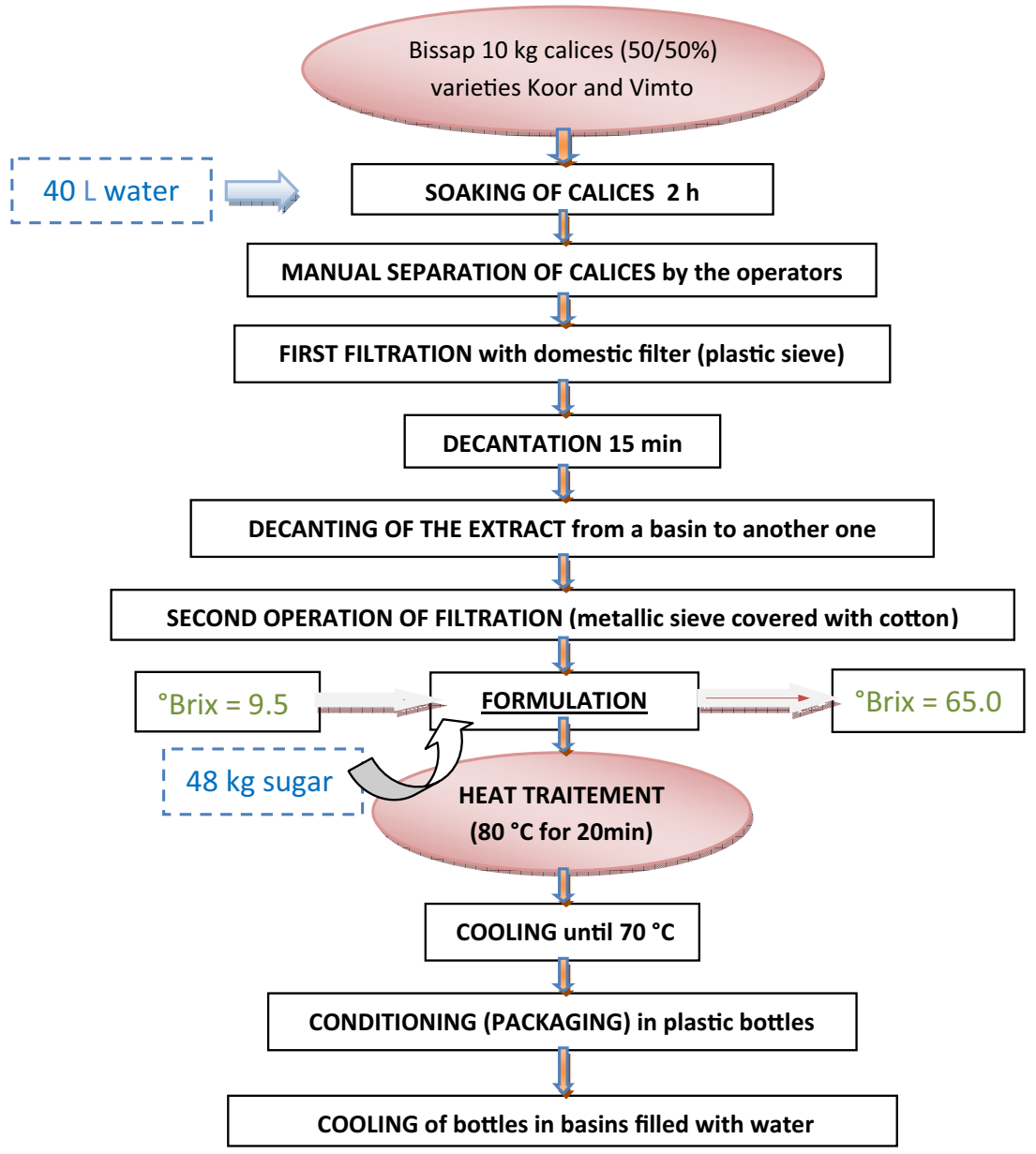

Figure 2. Logic flow in the process of bissap syrup (Hibiscus sabdariffa L.).

Table I. Physical, chemical and biochemical characteristics of the finished products produced from the calyx of bissap (Bechoff, Cissé et al. 2014) [20].

\begin{tabular}{|c|c|c|c|c|c|c|c|}
\hline & $\mathrm{pH}$ & $\begin{array}{l}\text { Total Soluble Solid } \\
\qquad{\mathrm{g} 100 \mathrm{~g}^{-1}}\end{array}$ & $\begin{array}{l}\text { Titratable acidity } \\
\qquad \mathrm{mEq} \mathrm{L}^{-1}\end{array}$ & $\begin{array}{l}\text { Total sugars } \\
\text { g } 100 \mathrm{~g}^{-1}\end{array}$ & $\begin{array}{l}\text { Reducing sugars } \\
\qquad{\mathrm{g} 100 \mathrm{~g}^{-1}}^{-1}\end{array}$ & $\begin{array}{l}\text { Anthocyanins expressed } \\
\text { as delphinidin-3- } \\
\text { xylosylglucoside } \mathrm{mg} \mathrm{L}^{-1}\end{array}$ & $\begin{array}{c}\text { Polyphenols } \\
\mathrm{mg} \mathrm{L}^{-1}\end{array}$ \\
\hline $\mathrm{COS}$ & $2.62 \pm 0.29$ & $16.93 \pm 2.49$ & $49.78 \pm 0.44$ & $17.39 \pm 0.08$ & $14.91 \pm 0.54$ & $60 \pm 1.88$ & $218 \pm 13.28$ \\
\hline
\end{tabular}

COI: commercial ordinary infusion; COS: commercial ordinary syrup.

using equipment disinfected by bleach (100 ppm of chlorine) for $30 \mathrm{~min}$, rinsed, drained and then dried. The stages of the transformation methods were almost identical to those already described $[8,19]$.

\subsection{Physico-chemical and biochemical composition of the finished products of Hibiscus sabdariffa}

The hibiscus beverage pasteurized at $80{ }^{\circ} \mathrm{C}$ for $20 \mathrm{~min}$ had $\mathrm{pH}$, total acidity, anthocyanins and polyphenols with higher values than the syrup pasteurized at $105^{\circ} \mathrm{C}$ for $20 \mathrm{~min}$ (table I). The degradation of organic acids and polyphenols including anthocyanins could be explained by a more severe pasteurization treatment for hibiscus syrup because the time to reach its boiling point was longer [20]. These results are consistent with those of Cissé et al. [8], who said that anthocyanins were affected by temperature.

The amounts of total soluble solids and total and reducing sugars were higher in syrups because the sugar added to calyces was higher for the syrup than for the beverage. During heating some disaccharides such as sucrose can be hydrolyzed into monosaccharides or reducing sugars such as glucose and fructose [21].

\subsection{Analysis of PCR-DGGE profiles}

The microbial diversity during the manufacturing process of juices and concentrates of bissap was studied by using the 
PCR-DGGE profiles obtained from the DNA microbial extracts (bacteria, yeasts and molds) extracted at all the stages of the bissap process (figure 3). Every vertical column represents a stage of the process and every spot represents a species of microorganism. The bands that were persistent in all stages of the process and those who were discriminative were cut and sequenced. In figures 3a, 3b, 3c the names of microorganisms obtained by sequencing of the bands of interest are shown.

The separation of amplicons was good during the migrations (figure 3) and the microbial diversity evolved differently during the process according to the type of flora. As regards bacteria (figure 3), certain species such as Agrobacterium tumefaciens were present on fruits of var. Koor but absent on var. Vimto and on the dried calyces. The microbial ecology of the bissap process was very complex. On the fresh calyces, certain bacteria of the environment such as Agrobacterium tumefaciens were found. They are usually responsible for gall disease in vegetables. This bacterium was also found by Bouzar et al. [22], who showed that the fruits in tree nurseries of Algeria were infected by this germ and the most affected botanical species were peach tree, almond tree, cherry tree, apple tree and olive tree.

On the other hand, other species such as Klebsiella sp. and Pseudomonas spp. were present on both varieties of fruits but disappeared during drying. For other stages of the processing (the drink before filtration up to the packaged syrup), a similar bacterial population consisting among others of Pseudomonas spp., Escherichia coli, Staphylococcus haemolyticus and Klebsiella sp. were noted at all the process stages before and after pasteurization. This demonstrates the obvious lack of hygiene of the staff and the factories.

For yeasts, the species Aureobazidium pullulans was found on both varieties of fruits but disappeared during drying. On the other hand, Pichia opuntiae persisted in the drink after pasteurization but disappeared in the manufacturing process of the concentrated juice (figure 3). The yeast Aurobazidium pullulans was found on the fresh calyces and Pichia opuntiae was noted at certain stages of the processing (sweet drink), which could lead to fast alcoholic fermentation. Indeed, Pichia presented a high fermentative activity when it was in the presence of strong concentrations of sugar. The catabolism of sugars by microorganisms was accomplished by a variety of metabolic pathways. Yeasts, as a group, are more homogeneous with respect to sugar catabolism than bacteria [23].

The study of the fungal population showed the presence of Aspergillus carbonarius and Penicillium viridicatum at all the process stages (drink and concentrate) as well as Aspergillus niger and Aspergillus tubingensis, which appeared at certain stages (figure 3c). The presence of molds of the genera Aspergillus and Penicillium was noted at all the stages of the processes. They were described as saprophytes and could also be responsible for the production of some mycotoxins when storing the calyces. These mycotoxins were found on certain plants such as coffee, corn, dried grape, etc. [24]. All this microbial ecology found in the bissap processing was very similar to that described in grape berries [25].

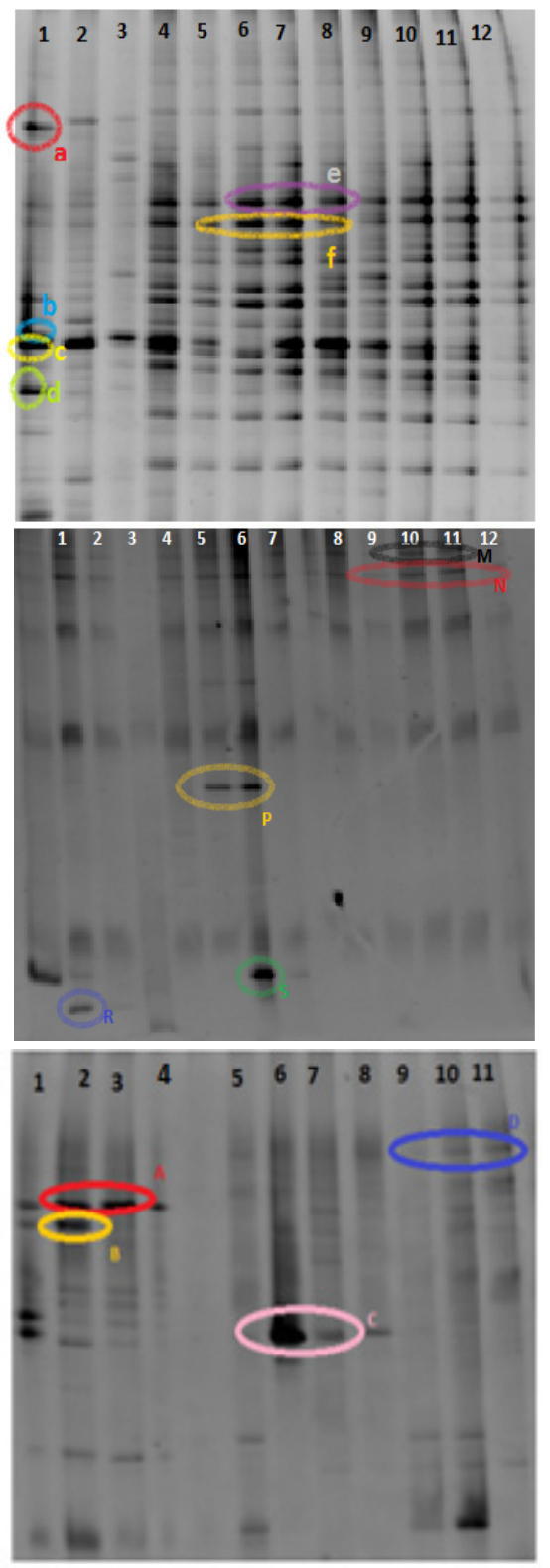

Figure 3. DGGE gels of various sampled bissap materials: (1) Fruit variety Koor, (2) Fruit variety Vimto, (3) Mixed dried calices, (4) Drink before filtration, (5) Drink after filtration, (6) Sweet drink, (7) Pasteurized drink, (8) Packaged drink, (9) Syrup after filtration, (10) Sweet syrup, (11) Pasteurized syrup, (12) Packaged syrup in bottle. 3a (top). Detection of bacterial DNA: a: Staphylococcus haemolyticus (99\% KF 696713); b: Escherichia coli (100\% AM 117601); c: Klebsiella sp. (99\% JX 178708); d: Agrobacterium tumefaciens (100\% KF577530); e: Pseudomonas sp. (100\% KF 601936); f: Acidovorax sp. (100\% KF 577530). 3b (middle). Detection of yeast DNA (sample number 12 is not present on the gel because of amplification problem): A: Aureobazidium pullulans (91\% JQ 418404); B: Hanseniaspora opuntiae (99\% KF263957); C: Pichia opuntiae (100\% EU 762030); D: Hanseniaspora uvarum (100\% EU 441886). 3c (bottom). Detection of mold DNA: M: Aspergillus carbonarius (99\% AY 540944); N: Penicillium viridicatum (100\% JN 121817); P: Aspergillus tubigensis (94\% KC 806053); R: Aspergillus nomius (98\% GQ 221261); S: Aspergillus niger (CET 2091, control strain). 


\subsection{Analysis of similarity of the dynamics of microorganisms during the various stages of bissap processing}

The typological analysis of the profiles of DGGE gel of bacteria, yeasts and molds for the samples of bissap during various stages of processing showed several types of groupings of microbial communities according to the stage of the process (figure 4). The analysis of the dendrogram of bacteria (figure 4a) showed several groupings, with $54 \%$ of similarity between bissap fruits of the var. Koor and Vimto, and 25.4\% of similarity between these groups and dried bissap. The bacterial ecology was very dynamic during the process. The reduction in the bacterial species on dried calyces (mixture of both varieties) was due to microbial mortality during drying. These results were consistent with those of coffees, where the number of bacteria was abundant on cherries, stable during the process, then halved during drying [24]. The bacterial flora found at the level of various stages (before filtration until packaging) presented similarity varying from $84.2 \%$ in the group of the sweet drink and pasteurized drink compared with the group of the sweet and pasteurized syrup. $100 \%$ of similarity was noted between the drink and the conditioned syrup. The appearance of new species at these stages was certainly due to the material, the staff and the working environment. This permitted concluding the existence of re-contamination after pasteurization. The lack of staff hygiene, unwashed equipment and also environmental contamination could be responsible for this phenomenon.

The dendrogram of yeasts (figure $4 \mathrm{~b}$ ) also revealed several groupings, with $80 \%$ of similarity between fruits of the varieties Koor and Vimto and $40 \%$ of similarity between this group and the dried bissap. The drying logically decreased the number of yeast species from 80 to $60 \%$, as was observed for bacteria. This could be explained by the fact that drying reduced the moisture from 86 to $16 \%$ for good preservation of calyces [8]. During other stages of the process, $100 \%$ of similarity was obtained between the sweet and pasteurized drinks. This showed that sugar favored the proliferation and/or the appearance of new species of yeasts that stayed thermostable during pasteurization. Certain yeasts degrade simple sugars by an oxidative process that leads to the production of water, carbon dioxide and a large quantity of energy responsible for their life growth and multiplication. Other yeasts transform sugars into alcohols. Yeasts can thus degrade the taste of the final products. Although the yeasts, like molds, were present in large number on the surfaces of fresh fruit, they do not have mechanisms to invade plant tissues, and are, therefore, secondary alteration agents [26].

The fungal population (figure 4c) had a very similar evolution to yeasts, with $85.7 \%$ of similarity between 'Koor' and 'Vimto', which also had $25.7 \%$ similarity with the dried bissap. The drying also decreased the fungal flora. During other stages of the process (before filtration until the conditioning), there was not much change in the fungal flora and the similarity of the species varied between 80.3 and $100 \%$. The acidophilus character of yeasts and molds could justify much of their proliferation $(\mathrm{pH}<4)$, in extracts of hibiscus sabdariffa that are naturally acidic. Fungal strains were certainly

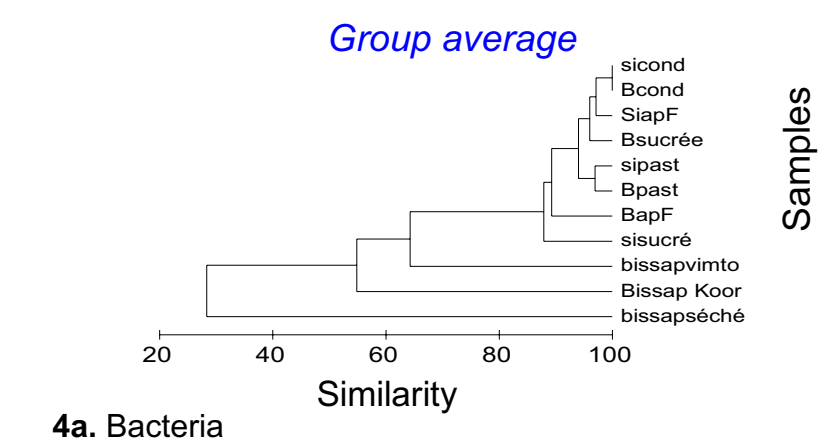

4a. Bacteria
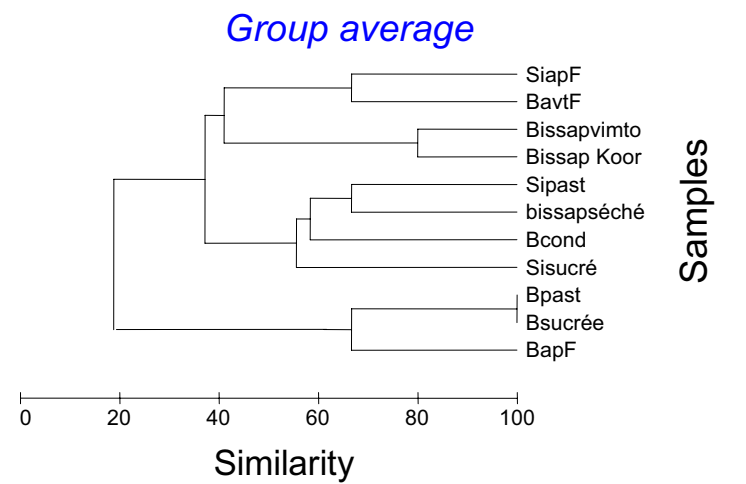

4b. Yeasts

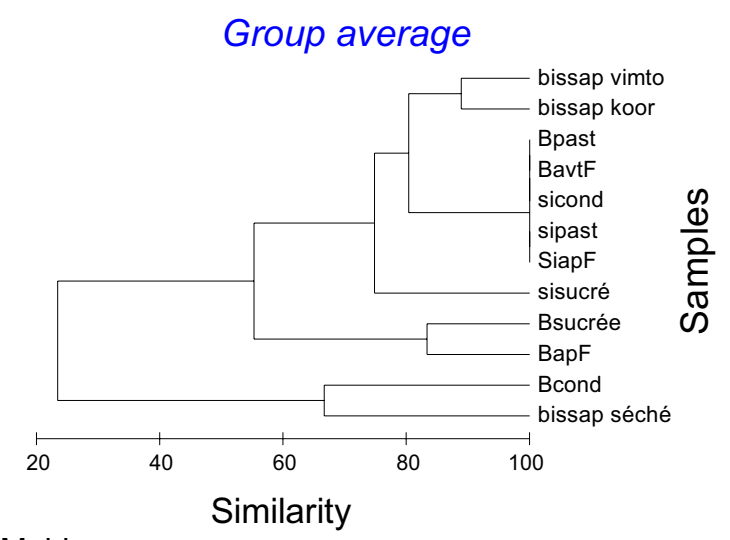

4c. Molds

Figure 4. Quantitative evolution of the various microbial flora on all stages of production of Hibiscus drinks and syrups. Bissap koor: bissap fresh calices variety koor; Bissap vimto: bissap fresh calices variety vimto; Bissap séché: dry mix of calices from two varieties of bissap; BavtF: beverage before filtration; BapF: beverage after filtration; Bsucrée: sweety beverage; Bpast: pasteurized beverage; Bcond: package beverage; SiapF: syrup after filtration; Sisucré: sweety sirop; Sipast: pasteurised syrup; Sicond: package syrup.

not involved in the process but were contamination from the environment.

The analysis of the three dendrograms showed a disparity of the microbial contaminants among three big phases: harvest (two varieties of fresh fruit), drying (dried calyces) and during the other stages of transformation (processing) of the drink and concentrate. Most of the microbial flora decreased during 
the drying but were very dynamic in the other stages (before filtration until conditioning). However, the presence of microorganisms after pasteurization showed that either the pasteurization was ineffective, or the product was re-contaminated after the heat treatment by the staff and the deficient processes of putting the products into flasks.

In fact, these sanitary practices are often lacking during the craft processing of fruits and vegetables in Senegal. The craft processing of bissap in the city of Maroua in Cameroon was often done in worse hygienic conditions than in Senegal, and the products obtained were of bad sanitary quality, which disadvantages their sale on the standardized markets [27].

\section{Conclusion}

PCR-DGGE was an effective analytical method which allowed following the microbial ecology during the processes of bissap transformation. The statistical analysis of the similarity showed the existence of cross-contamination of products with microorganisms of environmental and/or human origins. These contaminants can be responsible for grave sanitary disorders (Escherichia coli, Staphylococcus haemolyticus). They lead to problems of preservation of juices or the concentrates over time, or to the appearance of unpleasant tastes. In all cases, they will be a significant loss of income for the companies of this sector. These contaminants could be mastered with the implementation and application of good hygienic practice and manufacturing, and the establishment of the HACCP system on all the production line.

Acknowledgements. The bibliographical work was done in the framework of the AFTER project, and the author benefited from financial support from the World Bank (Robert S. McNamara scholarship), USAID/ERA project and PAPES project.

Conflict of interest. We proposed in this paper a traceability tool that allows controlling microbial flora associated with the juice and syrup of bissap for a private Senegalese company, to improve the quality of their products. There is no conflict of interest.

\section{References}

[1] Cisse M., Dornier M., Sakho M., Ndiaye A., Reynes M., Sock O., The bissap (Hibiscus sabdariffa L.): composition and main uses, Fruits 64 (3) (2009) 179-193.

[2] Morton J.F., Dowling C.F., Roselle, in: Fruits of warm climates, Climates, Media, Inc., Green-sboro, NC, USA, 1987.

[3] Harborne J.B., The flavonoids, Advances in research since 1986, Chapman Hall, London, 1994.

[4] Babalola S.O., Babalola A.O., Aworh O.C., Compositional attributes of the calyces of roselle (Hibiscus sabdariffa), J. Food Technol. Afr. 6 (4) (2001) 133-134.

[5] Kerharo J., Adam J.G. The traditional Senegalese pharmacopoeia Healing plants and toxin, Vigot Frères, Paris, France, 1974.
[6] Diouf M., Diop M., Lô C., Drame K., Sene E., Ba C.O., Gueye M., Faye B., Prospecting of vegetables sheets traditional of African type in Senegal, in: Chuweya J.A. Eyzaguine P. (Eds.), Biodiversity of traditional leafy vegetables in Africa, International plant Genetic Resources Institute (IPGRI), Rome, Italie, 2009.

[7] Diouf M., Lô C., Gueye M., Mbengue N.B., Participative selection of new cultivars of four (4) sorts (species) of vegetablessheets (Hibiscus sabdariffa L, Amaranthus L. spp, Vigna unguiculata (L.) Walp. And Moringa oleifera Lam.) in Senegal, Afr. J. Food Agric. Nutr. Dev. 7 (3) (2007) 1-17.

[8] Cissé M., Dornier M., Sakho M., Diop C.M., Reynes M., Sock O., Production of hibiscus (Hibiscus sabdariffa L.) in Senegal, Fruits (64) (2009) 111-124.

[9] Barth M., Hankinson T.R., Zhuang H., Breidt F. Microbiological spoilage of fruits and vegetables, in: Food microbiology and food safety, Springer Science+Business Media 2009.

[10] AOAC, Fruits and fruits products. In K. Helrich (Ed.), Official methods of analysis of the association of official analytical chemists international, VA: Arlington, 1990.

[11] Lee, J., Durst, R.W., Wrolstad, R.E., Determination of total monomeric anthocyanin pigment content of fruit juices, beverages, natural colorants, and wines by the $\mathrm{pH}$ differential method: Collaborative study, J. AOAC Int. 88 (2005) 1269-1278.

[12] George S., Brat P., Alter P., Amiot M.J., Rapid determination of polyphenols and vitamin $\mathrm{C}$ in plant-derived products. J. Agric. Food Chem. 53 (2005) 1370-1373.

[13] European Economic Community, Determination of reducing sugars expressed as invert sugar or dextrose equivalent; LuffSchoorl method, Off. J. Eur. Commun. 23 (1979).

[14] El Sheikha, Condur A., Métayer I., Le Nguyen D.D., Loiseau G., Montet D., Determination of fruit origin by using $26 \mathrm{~S}$ rDNA fingerprinting of yeast communities by PCR-DGGE: preliminary application to Physalis fruits from Egypt, Yeast 26 (10) (2009) 567-573.

[15] El Sheikha A.F., Durand N., Sarter S., Okullo J.B.L., Montet D., Study of the microbial discrimination of fruits by PCR-DGGE: Application to the determination of the geographical origin of Physalis fruits from Colombia, Egypt, Uganda and Madagascar, Food Control 24 (1-2) (2012) 57-63.

[16] Le Nguyen D.D., Ngoc H.H., Dijoux D., Loiseau G., Montet D., Determination of fish origin by using $16 \mathrm{~S}$ rDNA fingerprinting of bacterial communities by PCR-DGGE: An application on Pangasius fish from Viet Nam. Food Control 19 (2008) 454460.

[17] Thompson J.D., Gibson T.J., Higgins D.G., Clustal W., Improving the sensitivity of progressive multiple sequence alignment through sequence weighting, position-specific gap penalties and weight matrix choice. Nucleic Acids Res. 22 (22) (1994) 4673-4680.

[18] Osborn M., Smith C., Molecular microbial ecology (advanced Methods), Taylor \& Francis US, 2005.

[19] Bayoï J.R., Djoulde D.R., Maiworé J., Bakary D., Essome J.S., Noura B., Tcheme G., Tchiosah R., Ngang J.J.E., Etoa F.X., Influence of manufacturing process on the microbiological quality of folere beverage (Hibiscus sabdariffa) sold in three towns of Cameroon: Maroua, Mokolo and Mora, Int. J. Innov. Appl. Stud. 9 (2) (2014) 786-796. 
[20] Bechoff A., Cissé M., Fliedel G., Declemy A-L, Ayessou N., Akissoe N., Touré C., Bennett B., Pintado M., Pallet D., Tomlins K.I., Relationships between anthocyanins and other compounds and sensory acceptability of Hibiscus drinks, Food Chem. 148, (2014) 112-119.

[21] Lamberts L., Rombouts I., Delcour J.A., Study of nonenzymic browning in a-amino acid and c-aminobutyric acid/sugar model systems, Food Chem. 111 (2008) 738-744.

[22] Bouzar H., Daouzli N., Krimi Z., Alim A., Khemici E. Crown gall incidence in plant nurseries of Algeria, characteristics of Agrobacterium tumefaciens strains, and biological control of strains sensitive and resistant to agrocin 84, Agronomie 11 (10) (1991) 901-908.

[23] Johannes P., Dijken, V., Scheffers, W.A., Redox balances in the metabolism of sugar by yeasts, FEMS Microbiol. (32) (1986) 199-224.
[24] Durand N., Microbial population dynamics during post processing coffee harvest and interspecific interactions between stem ochratoxinogenic, University of Montpellier II, France, Thesis, 2012, 124 p.

[25] Barata A, Malfeito-Ferreira M, Loureiro V., The microbial ecology of wine grape berries, Int. J. Food Microbiol. 153 (3) (2012) $243-259$.

[26] Alzamora S.M., Cerrutti P., Guerrero S., López-Malo A., Minimally processed fruits by combined methods, In Food preservation by moisture control-fundamentals and applications, Welti-Chanes, J., Barbosa-Cánovas, G. (Eds.), Technomic Pub. Co. Lancaster, USA (1995) 463-492.

[27] Folefack, D.P., Njomaha, C., Djoulde, D.R., Diagnosis of the system of production and marketing of the juice of sorrel of Guinea in the city of Maroua in Cameroon, Tropicultura 28 (4) (2008) 211-215. 